\title{
The Functions of Art in Conveying the Meanings to Audience (Case Study: Some Selected Images from the Earthquake of Bam, 2003)
}

\author{
Mohamadjavad Mahdavinejad*, Kowsar Afzali, Akram Ahmadi, Mahsa Noruz, Arash Amin \\ Faculty of Art, University of Tarbiat Modares, Tehran, Iran \\ *Corresponding author: Mahdavinejad@modares.ac.ir
}

Received October 27, 2013; Revised November 30, 2013; Accepted February 09, 2014

\begin{abstract}
Art, depending on its properties, has an expressive language and if a concept accompanies it, or being said in an artistic language, it would be eternal, too. A review of the literature shows that the artworks, directly or indirectly, reflect the philosophy and idea of the artist, by which he has created the work. Thus any art piece has a negative or positive message to his audience and would affect him in one of these two trends. The Educational outcomes of these two approaches, has a long term and strange effect on the audience. The Article in addition of analyzing these approaches in photos of the Bam earthquake, analyses the orientation of artworks being produced after that and its impact on the audience. The research results show that the art can have wide conceptual effects on the audience. The analyzed samples indicate that some of the images emphasizing the positive implications from devastations of the earthquake, associations hope and mobility to audience. On the other hand, some of the images by showing negative concepts associate despair and hopelessness. The dual and also significant impact of art works shows that during the natural disasters and damages, we can use it as a factor in improving the situation and helping injured victims.
\end{abstract}

Keywords: the function of art, art and conveying information, artwork

Cite This Article: Mohamadjavad Mahdavinejad, Kowsar Afzali, Akram Ahmadi, Mahsa Noruz, and Arash Amin, "The Functions of Art in Conveying the Meanings to Audience (Case Study: Some Selected Images from the Earthquake of Bam, 2003).” American Journal of Educational Research, vol. 2, no. 2 (2014): 66-72. doi: education-2-2-1.

\section{Introduction}

The city of Bam is located in the eastern of Kerman province and southwest edge of the Loot desert. At dawn (5:20) on $26^{\text {th }}$ of December 2003 a strong earthquake centered near the town, with the intensity equal to $3 / 6$ Richter, destroyed city and killed half of the residents. After the disaster many artists focused to reflect the event. Some of the artists have always looked at the problems beyond feelings and emotions, and a little higher than pain, sorrow or sadness. They have tried to survive hope between disaster victims and to change their sight from destruction and distress to prosperity and life expectancy. They want to spread the positive and effective vision in the society, and another group has shown the incident without considering the effective language of art.

One of these impressive arts is photography which has always been so important in capturing the interesting moments of people's life. "Photography is the language of silence and a photo makes hidden sides of the places and events to be appeared" [1].

Donna Stein says in the introduction of his book: "Photography which is pioneer in the modern visual communication, has a great impact on our Ideology and has changed what we see. Good photos increase our ability to view the world that was previously unknown and unclear. The photographs sometimes in relation with anthropology lead us to understand some part of people's life much more better than any oral descriptions and expression”. An ethnographer photographer pays attention to the most delicate scenes of people's life, that may had been far from many of the researchers view. Camera is hunter of the scenes, quieter of the views and finder of the critical points in people's life" [1]. In fact, the ethnographer photographer captures the subjects with special intelligence and delicate in order to have a message to his audience. By this way the messages transfer to audience with a direct or indirect expression. The photo as an artwork is intermediary between artist and audience and would change into a group experience. The artist is aware of his duty and responsibility. He knows that he should express anything that keeps the values and believes of people alive. Therefore, with his special artistic talent makes the ideology of the society involved in his work. The artist which is a compassionate one and is present among the people inspires from nature and its secrets and leads the eyes and minds of the audience toward the sky and the spiritual worlds. He provides a special spiritual atmosphere for the people and feeling of brotherhood to each other. In this way an artwork is a 
present world in front of the audience's world, which has their hidden and clear reactions which take place according to their belief in common values.

Plato and Tolstoy believe that the kind of art which the audience faces to is effective on his humanity belief. Long watching at the artwork, permanently seeing the works that there are special moral and ontological believes in them, and even the color or music, convey this items to audience. The artwork and its creator are different in their reactions to artworks and the shape of this reaction [2].

Unfortunately the role and base of art in conveying the indirect implications have not been specialized seriously yet and we have not enough documents in this case.

\section{Question and Methodology}

\subsection{Research Purpose}

1. Reuderstanding the direct and indirect messages in photography and Explainingits mechanism of transmission to the audience.

2. Understanding approaches of artists in photos that related to bam earthquake event and analyzing their effect on the audience.

3. Giving Suggestion and strategies to improving the effective role of artists in conveying indirect concepts to audience.

\subsection{Research Questions}

1. How direct and indirect message Transmits to audience?

2. What are the approaches of photographers to transmit message to the audience in the bam earthquake experience, 2003?

3. What strategies can be offered to audience to improve the effective role of artists for conveying the concept?

\subsection{Methodology and Select Samples}

Research method is content analyses. Selecting the cases is from the list of photographers who worked in this field and 50 photos is randomly selected.

\section{Art and Convey the Artistic Concepts}

Language is a communication tool that helps people not to be alone and communicate with each other, to understand each other and make mental relation to each other by the similar symbols and work coordinate. So language is a correlation factor which would be more or less strong based on that we use gestures language, or words language. When art is a language, it would be a tool for social correlation, too. And in addition because we aren't dealing with a system of symbols and ideas, and we have to deal with a system of emotional symbols. The correlation that is created by these institutions would be closer than the one which is created by the expressed words [3].

Language, is the most perfect manifestation of human life and art, is the most eminent pinnacle of human's life. Artistic language and standard language mean the language that is a tool for expressing human feelings and emotions in communities and both are expressive. It means they are the same in transferring emotions, feelings and human's needs [4]. So visual arts and especially photographs can communicate the audience of works during various events, and to have great effect in conveying direct and indirect concepts.

Christopher Kadvl says about the nature of art: "art changes content of human emotional consciousness, to be able to have more conscious and deeper react to the world. This penetration to inner reality, affects the hearts of human beings and this common sense reaches the entire community to a new level of empathy, understanding and compassion among human beings" [5].

The long experience of human in the process of history, suggests that speaking with the language of art is immortal and eternal, and would transfer and introduce to future generations pristinely and purely [6].So when art goes from community to person, it is a kind of regularizing to enthusiasm of humanity, and when he goes toward the society, it is opposite. It is here that we face to influence of art on political life [3] and we can interpreted This to relation between artist, artwork, audience and community that most of the theorists have emphasized on that. Today, in over the world the effect of art is known on the human's psyche. Culture of loving art and artistic expression is attended since the young age and it is trying that human get more familiar with the art to avoid the social and psychosocial trauma. We use art to cure most of the distresses and even identify social and personal mental problem. In some cases, to influence the world public opinions, we use art intelligently and we can conclude that art mingled with the human nature [7].

Artist is the source of art. If he doesn't create an artwork we can't name him source of the art and this statement is extremely clear and stable. Because it's imagination causes to admit. The artwork is like a defective that shows its most important factors with actualizing the art object significantly. The artwork is the best sample that is provided possibility realization of beauty by the artist [4]. The artist even to create his most privacy work follows the social, moral, emotional and political developments or gives the perception of these developments to future. Using his skills and plenteous talents, the artist tries to create a concept, Sense, message nicely and has a mastery sense to the work that he is creating and does it consciously [5]. It means that without creating a common sense which begins from a subscription in value principles. It is not possible to change audience's world and to induct new impacts, unless the artwork would be able to create a new interest and trend in viewer or audience [7]. Understanding the relationship between the artist (identified or anonymous) and audience (the people) is important to study the artwork, and that is why we can see a successful process between art and social life. On one hand, the process of mental activity based on social experience means the whole concept of individual creativity in the creator at the time of aesthetical invention. It places a message or concept with a common and familiar code in a physical framework, and puts it in front of the audience in an appropriate context. On the other hand, if the process of shaping and demonstrating the art piece is reach enough in the community, decoding takes place by the audience. 
Using nonverbal codes, he transferees his understanding to the artist. The Artist corrects his ideas and imaginations according to the reaction of the audience. So, the positive feedback from the creator of this process is communicative and a mutual conversation takes place between the artist and audience.

The understanding of audience through his recipient depends on his deep beliefs and can lead to a Performance based on effect and impression. Hans Robert Jauss in his theory "The Aesthetic of Reception" has emphasized on the relation between Artist, work and audience and believes that the artwork is a base for having relationship with audiences. W. In garden also believes that the work is just a set of plans and general directions that audience should realize them. To do this audience enters previously certain knowledge in the work and it has not any inconsistency with the necessity of understanding audience by creator. This knowledge is necessary to cause using familiar elements in sharing messages in order to reach the result, which is the communication through the artwork [9]. And the artist with knowing the audiences selects his approaches to conveying concept in his work and thus he can communicate with the audience And would give his intended message to society.

\section{Theoretical Framework}

Art is born from Thinking, pondering and fine feeling and has the best effect on human. The messages that have used effective artistic practices have been more successful. Tolstoy defines a kind of art that its goal is to communicate with audience and says: "The artist has a goal and that is transferring feeling that the artist has experienced and tested to human.”

Art should feels an inner necessity for the emotion transmits [10]. Therefore we can identify a tendency among the artists that its purpose is to convey meaning to the audience and influencing him. We are speaking about the arts that have an educative an principal role in community. In fact the artist offers two types of messages to audience with his work. The message which is inherently positive and always has effective and desirable effects on the audience and the other is a negative message that would have unpleasant effects on the audience. In other words in the cases of difficulties and hardships such as the Bam earthquake Art can plays two types of roles, positive role and negative role. And the attitude of the artist can make the society weak or strong in dealing with problems. The artist can encourage society to achieve a bright future more rapidly with his positive attitude or by his negative attitude and the meanings which expresses directly or indirectly in his work, brings disappointment in society. So here the artist must be aware of the social context of his artworks. Artworks transmit particular messages or feelings which call the viewers sometimes apparently unconscious and indirect, and sometimes consciously and directly. Selecting the pictures correctly, we can note indirect training like advice, Warning, and stressed out, giving reasons, encourage and motivating and etc in addition to direct teaching; that all can be helpful, in promoting the spiritual dimensions. So images are a factor to impress social-cultural behaviors and values [11]. Do we have allowed to ignore the audience and show him whatever we want, or we should choose? We can acknowledge That general criteria to measure the Katarsys definitions, is its coincident in creating the sense of peace in audience's group, That comes into existence from the impact and induction of artwork. Creating the calm is when doing the work according to acceptable values. This principle can be true for all people, because everyone is mostly aware of his acts and impacts than the accepted values in its good kind. Does advising sentences can influence the audience, or it is better to induce him the message indirectly? Kraysl believes that although media cannot be successful in how we think, but it is successful in what the audience thinks to [12]. Some people are convinced more difficult, because the audiences and listeners of the message are not the same. Audiences based on their mental pre-assuming will be exposed to the message. A successful message is what they're not any previous opposition to that or its similar messages, in the mind of the audience. When people face to a message that it is against their beliefs, they tend to distort its meaning, or create opposite reasons immediately. Thus audiences are able to avoid change their opinion [13].

Based on the mentioned facts, the way we watch the effect of artwork has the same fate in the audience. This is the problem that this text tries to study. There is a question and concern for any artist who is the owner and creator of an artwork and finishes the artwork by his mental and emotional frame, if his artwork can convey his feelings and thought to audience? Perhaps this question is important For all artists because the artist becomes so happy and exited if his audience is shared in his sense. The artist is successful when is able to create effect and reaction in his audience. Creating the desired reaction and effect in the audience, is very important that almost carries the hidden purpose of the artist [14]. The same purpose in all the artworks is to create an effect in audience or artist himself, either individual or collective. Now what is this effect and impression, and how it should be achieved? How should we know about it? And what features should this interaction have? [14]. These are the topics that have been expressed for the first time by the Greek philosopher and critic, Aristotle in his book, "The Techniques of Poetry" with details.

Table 1. Positive and negative messages in the artworks and examples of the seconcepts in the images from Bam earthquake (Source: authors)

\begin{tabular}{|c|c|c|c|c|}
\hline $\begin{array}{l}\text { Ro } \\
\text { W }\end{array}$ & $\begin{array}{l}\text { Positive } \\
\text { message }\end{array}$ & $\begin{array}{l}\text { Examplesin } \\
\text { pictures }\end{array}$ & $\begin{array}{l}\text { Negative } \\
\text { messages }\end{array}$ & $\begin{array}{l}\text { Examplesin } \\
\text { pictures }\end{array}$ \\
\hline 1 & $\begin{array}{l}\text { Hope and } \\
\text { desire }\end{array}$ & Smile & $\begin{array}{l}\text { Disappointme } \\
\text { nt }\end{array}$ & $\begin{array}{l}\text { Tearsandsig } \\
\text { hs }\end{array}$ \\
\hline 2 & $\begin{array}{l}\text { Determinatio } \\
\mathrm{n}\end{array}$ & $\begin{array}{l}\text { Renovationan } \\
\text { d Restoration }\end{array}$ & $\begin{array}{ll}\text { Fear } & \text { and } \\
\text { horrors }\end{array}$ & Destruction \\
\hline 3 & $\begin{array}{l}\text { LifeandLivin } \\
\text { g }\end{array}$ & Rose-Growth & $\begin{array}{l}\text { Death and } \\
\text { destruction }\end{array}$ & $\begin{array}{l}\text { The bodies- } \\
\text { empty, dark } \\
\text { andfear } \\
\text { space }\end{array}$ \\
\hline 4 & $\begin{array}{l}\text { Activity and } \\
\text { Mobility }\end{array}$ & $\begin{array}{l}\text { work } \\
\text { Andexciteme } \\
\text { nt }\end{array}$ & $\begin{array}{l}\text { Isolation and } \\
\text { lonely }\end{array}$ & $\begin{array}{l}\text { Silence- } \\
\text { HauntedCity }\end{array}$ \\
\hline
\end{tabular}

In critical times Such as earthquakes an artist has to understand how to put the meaning in an artwork in order to convey the most amount of messages. Such an issue causes the audience enjoys the work (even undesirable) and admire it or to have an opposite effect on him. Here the important thing is that a message is conveyed correctly and beautifully, when it is marked perfectly. In table 
number 1, some cases of these positive or negative messages and their examples are mentioned to see and understand the relation between artist, artwork and audience. In table number 2, the evoked Messages in audience's minds are gathered from 50 samples of earthquake is listed that are classified in positive and negative categories. It should be noticed that each one of these messages and attitudes have been studied individually for each of the images, which has been shown In Table 3.

Table 2. Indirect implications (Positive and negative messages) In 50 photographed samples of Bam earthquake (Source: authors)

\begin{tabular}{|l|l|l|l|l|}
\hline $\begin{array}{l}\text { Activity } \\
\text { and } \\
\text { Mobility }\end{array}$ & $\begin{array}{l}\text { Life and } \\
\text { Living }\end{array}$ & Determination & $\begin{array}{l}\text { Hope and } \\
\text { Desire }\end{array}$ & $\begin{array}{l}\text { Positive } \\
\text { messages }\end{array}$ \\
\cline { 1 - 4 } Satisfaction & Charming & Sympathy & Pride & \\
\hline $\begin{array}{l}\text { Isolation } \\
\text { and lonely }\end{array}$ & $\begin{array}{l}\text { Death and } \\
\text { destruction }\end{array}$ & Dissapointment & $\begin{array}{l}\text { Fear and } \\
\text { horrors }\end{array}$ & $\begin{array}{l}\text { Negative } \\
\text { message }\end{array}$ \\
\cline { 1 - 4 } Pain & Devastated & Ashamed & Discomfort & \\
\hline
\end{tabular}

Table 3. Sample Questionnaire has been completed From Positive and negative messages from image 1 (Source: authors)

\begin{tabular}{|l|c|l|}
\hline $\begin{array}{l}\text { Positive } \\
\text { messages }\end{array}$ & & Description \\
\hline Hope & $\checkmark$ & $\begin{array}{l}\text { Looking to the } \\
\text { distant and future } \\
\text { skyline }\end{array}$ \\
\hline Determination & $\checkmark$ & $\begin{array}{l}\text { Tryinghardto } \\
\text { reconstruct }\end{array}$ \\
\hline Life & $\checkmark$ & Rose/Growth \\
\hline Activity & $\checkmark$ & $\begin{array}{l}\text { Work } \\
\text { andexcitement }\end{array}$ \\
\hline Pride & $\times$ & \\
\hline Sympathy & $\checkmark$ & Collective effort \\
\hline Charming & $\times$ & \\
\hline satisfaction & $\times$ & \\
\hline $\begin{array}{l}\text { Negative } \\
\text { message }\end{array}$ & & Description \\
\hline dissapointment & $\times$ & \\
\hline Fear & $\times$ & \\
\hline Dead & $\times$ & \\
\hline Pain & $\times$ & \\
\hline Lonely & $\checkmark$ & $\begin{array}{l}\text { The man who is } \\
\text { planting a flower } \\
\text { in isolation. }\end{array}$ \\
\hline Ashamed & $\times$ & \\
\hline Devastated & $\checkmark$ & $\begin{array}{l}\text { Destroyed and } \\
\text { ruined area }\end{array}$ \\
\hline Discomfort & $\checkmark$ & Sad face \\
\hline
\end{tabular}

\section{Analysis of Samples}

Natural disasters, human violence, wars and etc are the events that always have been attend by the artists. During crises and events photographer Have captured Images that would never vanish from the visual memory of the society, And even in some cases, these pictures have had significant impacts on society and can remember some concepts of the event for audience always and in any time. In other words, through millions of photos which record from thousands of accidents or incidents in the world, few photos get persistent In pictorial history of a society and it depends on the level of intelligence, special look, speed of photographer and also the message of subject. Bam earthquake in 2003 was so considered by the artists and especially photographers, because of The high rate of human toll, financial and cultural damages. And consequently many visual documents were collected.

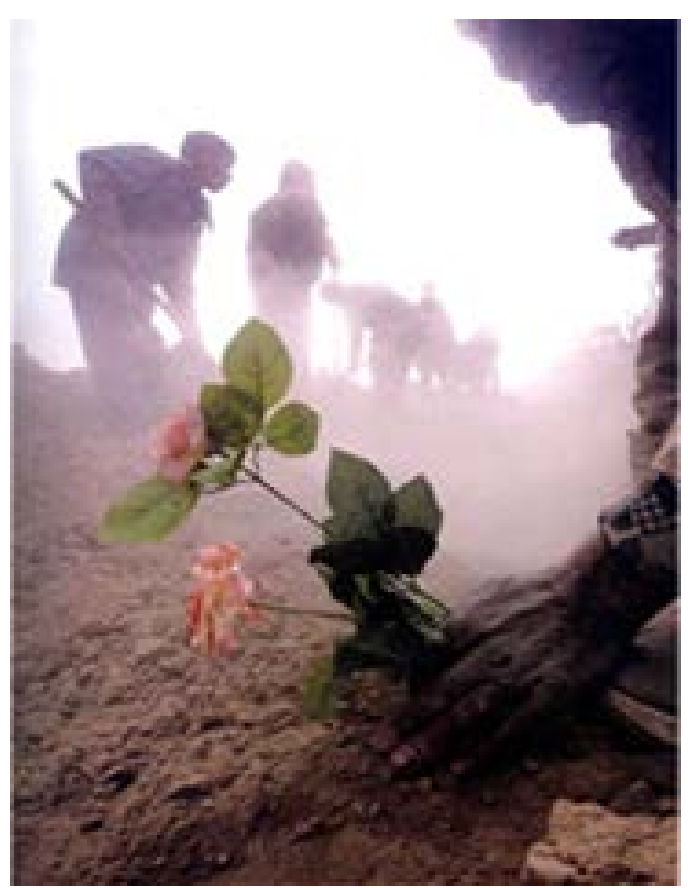

Picture 1. By MahdiGhasemi [15]

Hundreds of photographers were involved in this tragic event and prepared hundreds of thousands images about it but among these few pure photos noticed, that these photos through messages they had could Have positive or negative effects on audience. Here two different views is analyzed. In both approaches artists are as the narrator of a story because of direct deal. Both have spoken from an event and both are intended to describe one event. But two different views can be concluded from this photo. That in an event which of the views is prefers? To do this study, 50 photos are selected and each one has been commented according to mentioned words in theoretical principles. Considering that name of the work could have effect on commenting, it is avoided in the subtitle of images so that the audience expresses just his personal deduction. It is noted that these implications have not been far from the view of a photographer, such as the picture number 2 and 4 , which the photographers of these pictures have had positive and negative attitudes respectively, and audience has had the same presumption from these three pictures. In this section between 50 gathered photos of Bam earthquake, 6 photos (3 photos with positive attitude and 3 with negative attitude) are examined. The first image (Image 1) shows a devastated And haunted area in which a person is trying to reconstructs and repairing on top of a pole. It is full of determination and volition of rebuilding the life. Another photo Indicates the artistic and elegant view of the photographer that has taken it with a different view from the tragic atmosphere of the earthquake (Picture 2). The first plan of this photo is a person with wretched but solid and firm hands, who is planting a beautiful flower in a dead and inexistence soil, as a sign of life and reconstruction and a Row of people in the bright background of the picture who are working and trying to bring order to the current situation is a symbol of empathy and activity and excitement. And on the other hand the look of a working man with a curved back to glittery skyline is a sign of hope to a bright and uncertain future. What can be said about this photo is Level of intelligence, right angle, selecting the right lens and good frame and 
photographer's speed that has captured this memorable moment and seeing it in any situation would have a desirable impact on the audience. Once again, it can be seen that the positive and smart attitude of the photographer in this photo (Image 3) is well reflected. The photographer has documented confluence of two views with a pleasant smile among the extensive damages and the ruins of the city.

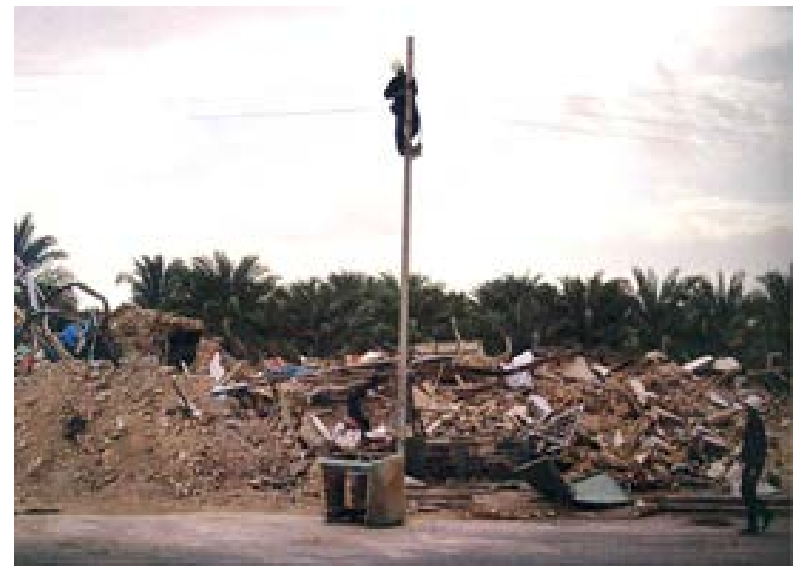

Picture 2. By MajidSaeidi [15]

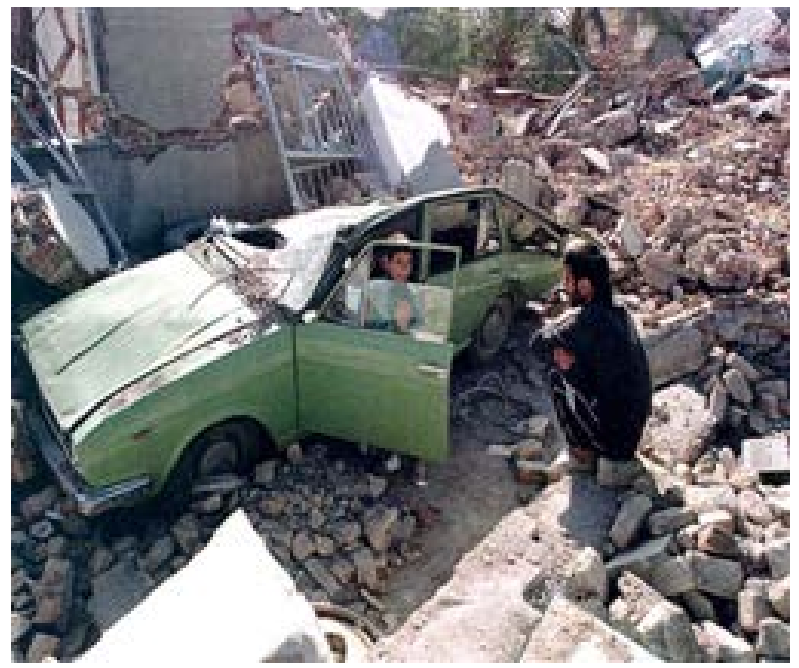

Picture 3. By Mojtaba Aghaee [15]

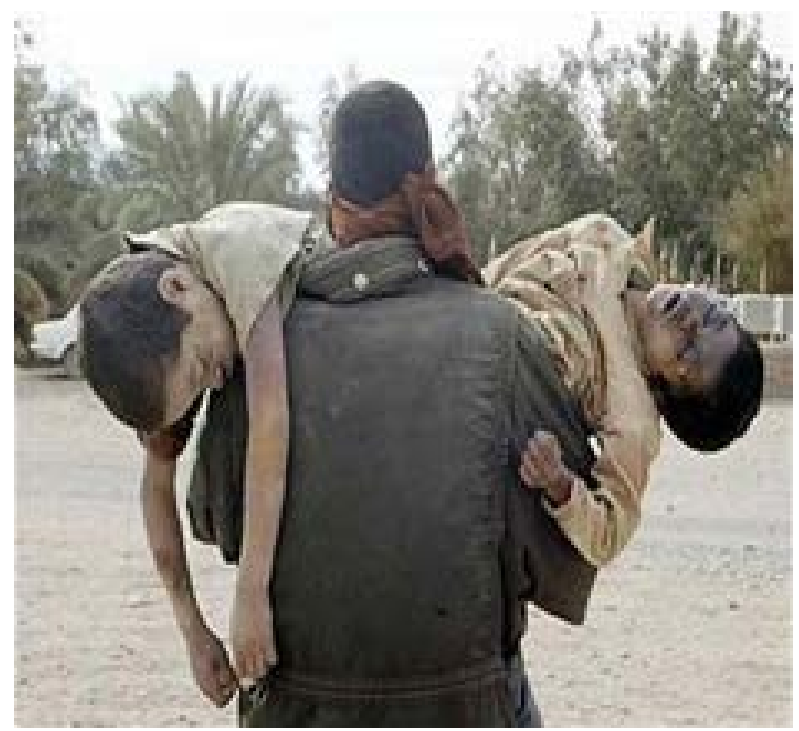

Picture 4. By Atta Allah Taher Kenareh Saeidi [15]
Another photo (picture 4) is a Father's picture who carries out his two died sons as he would never want to bury them. Photographer had been able to record a historical tragedy with this photo forever. In this photo there are not any traces of life stream, and you think that life is finished and the father cannot walk. Although the artist has tried to make this pure moment persistent, but the sad sense of photo can have an undesirable effect of audiences. Death and inexistence, horror and a mourning city are some of the meanings that associate in the mind of audiences, by looking at this photo (picture 5).

A destroyed city, the white and black colors which have made the mourning and sad space of the city more badly, are all the elements which have arranged in a exaggerated mode to show a scene of an earthquake.

And the last one (picture 6) is a picture of a poor kid which has slept in a ruined, vacant of people and dusty space. Solitude and fatigue, seclusion and unsociability is clearly seen in this picture.

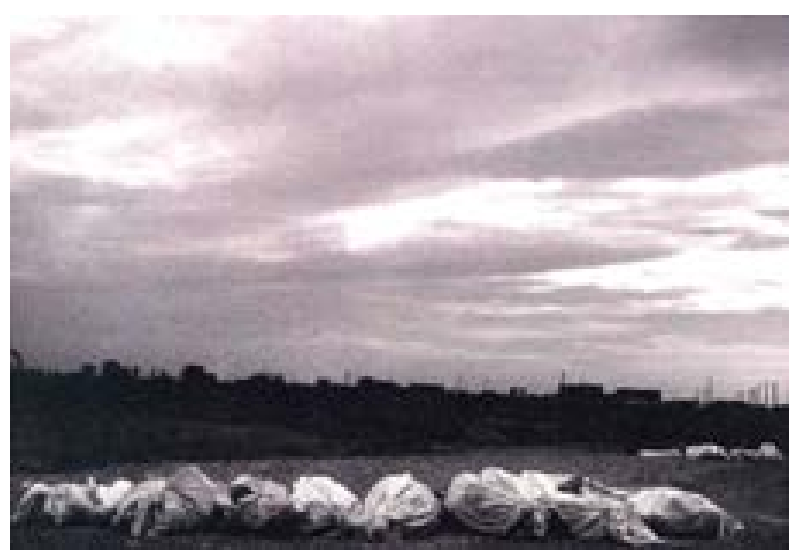

Picture 5. By Najaf Shokri [15]

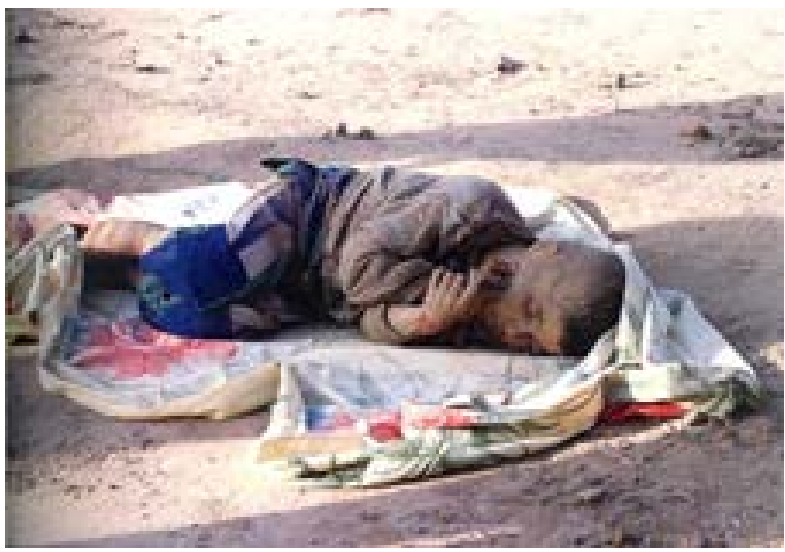

Picture 6. By Abasalt Bayat [15]

\section{Discussion}

The diagram shows the amount of positive or negative attitude in 50 gathered samples of Bam earthquake. Some of the pictures have one meaning (positive or negative) and some other carry several meanings. As it is seen in the diagram, in the visual samples, the positive messages such as satisfaction, attractiveness, empathy, pride, activities and movement, life, determination, hope and longing (which are shown in dark color in the diagram), had in order $30 \%, 10 \%, 70 \%, 21 \%$, 30\%, $78 \%, 50 \%$ and $70 \%$ in 
conveying the meanings. And also the negative messages such as pain, destruction, shame, sadness, isolation, loneliness, death and destruction, fear and despair, show in order the scores of $33 \%, 60 \%, 11 \%, 44 \%, 20 \%, 35 \%$, $11 \%$ and $20 \%$. analyses of the data in 50 cases show that most of the photographers have attended to positive messages more than negative ones.

The outcomes of the test shows that the meanings such as life and living with 78\%, hope, enthusiasm and empathy both with $70 \%$ had the most score in positive attitudes in conveying these indirect meanings. As you see the positive meanings and messages have been more in these photos and it shows that the artists are completely aware of the effects of art and try to distribute the positive attitude in such positions by expressing the messages such as life, empathy and construction, operations and excitement and other effective messages.
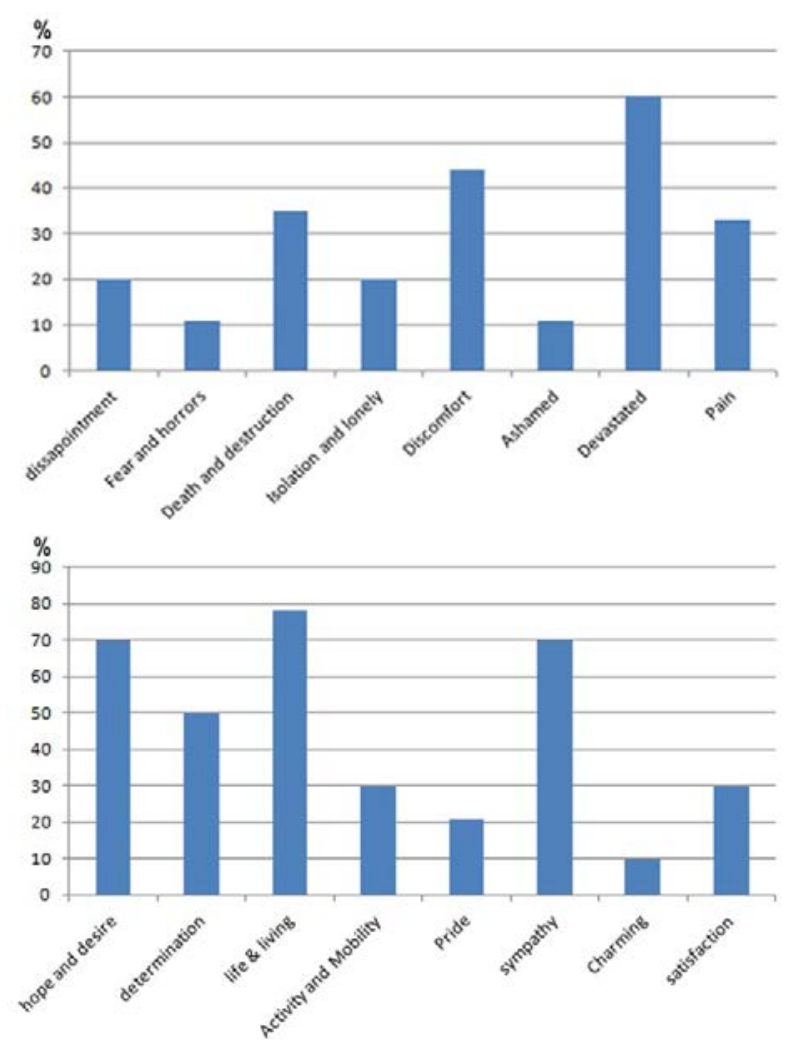

Figure 1. The ratio of positive and negative attitudes to captured images of Bam (Y-axis shows percentage amount of positive or negative attitude in 50 gathered samples of Bam earthquake) (Source: authors)

\section{Conclusion}

The art is the instrument of communicating with other people that in addition to direct contact provides the indirect and conceptual communication between humans, too. Different purposes can be proposed, that one of them is the role, value and ability of art in communicating between the artists and the community.

Here, the important fact is the power of the artist to affect the community through his artistic expression. And this gets more important in critical time. In fact, this is a great and deniable duty of the artists to put foot in this way when a disaster is happened and to struggle to express the values which promote the awareness, beauty and unity. And so the artists in the disasters such as earthquake can play an important and fundamental role by inducting the positive concepts and introducing the beauties and goodness through the understandable and familiar words and languages to all.

Art is necessary to the happiness of the people and community. Because it joins the people with a common sense. The tests had Substantial points that by using them in the process of conveying information indirectly through art can be very useful and helpful. The wonderful fact is that, results show that the positive messages have understood through the words such as: Life, empathy, hope and longing.

In other words the artworks that are associated to positive attitudes somehow would remind hope and continuation of life. The concepts that can be use in conveyance the indirect and values-based concepts. So it is recommended to pay special attention in creating the artworks. And that is clear that it would have greater effect on the audience then. In religious facts it is strongly emphasized on collectivism and inviting the believers to work as a team (empathy, and determination). So it is important that in creating the artworks or the works that are designed and created to promote positive attitude in the critical positions, we pay attention in this fact that and the tests show that most of the artist are aware of this fact and try to convey them to their audiences.

The achievements of the research show that art can have wide conceptual effects on the audience. The analyzed samples indicate that some of the pictures by emphasizing on positive meanings from the destructions of the earthquake bring hope and movement to the audience. And on the other hand some of the pictures, showing the negative concepts associate Spirit of despair. The two sided and also important effect of the artworks requires that in the case of natural disasters, to be used as an effective fact to improve the situations and to help the victims.

\section{References}

[1] Anasori, Jaber, Artistical Anthropology and Psychology, Espark Publication, 1989.

[2] Mahdavinejad, Mohammadjavad, The World Architectural Theories, Jahad Publication Ltd-University of Tehran, 2009.

[3] Bastied, Roje, Art and Society, Translator, Ghaffar Hosseini, First Printing Tehran, Toos publications, 1996.

[4] Norouzitalab, Alireza, 2010, An Inquest in The Morphology of Artistic Work and Getting Mean, Bagh-e-Nazar, No. 14, pp. 69-86.

[5] Kadvel, Christopher, About Literature and the Art, translator: Mehdi Asgharzadegan, Negah Publications, 2004.

[6] Hakim, Abdolrasoul, the role of art in education, master's thesis, Department of Culture and Education, The Center of Art University, 1988.

[7] Mahdavinejad, Mohammadjavad and Afzali, Kowsar, 2011, The Role of Art in Spiritual Education, Research Institute of Education Studies, No. 108, pp. 91-107.

[8] Norouzitalab, Alireza, 2008, Formal theory, The Base of Criticism, Interpretation and understanding the artistic works, pp. 69-88.

[9] Zarezadeh, Fahimeh and Rahbarnia, Z., Cooperative Interaction Between Creators and Audiences of Mourn Palm, The AnalyticResearch Quarterly of Islamic Art Studies, No. XI, 2002, pp. 4358.

[10] Tolstoy, Leo, What is the Art? Translator Dahgan Kaveh Tehran, Amir Kabir Publications, 1985.

[11] Afzali, Kowsar. Explaining the Iranian-Islamic Patterns in Teaching the Basics of Visual Arts, 2012.

[12] Kraysel, Andrew, Understanding Radio, Translator Essam Masoumeh. Tehran: Research and Development of sound, 2002. 
[13] Kia, Ali Asghar and Saedi, Rahman, Basic Relation of Advertisement and Satisfaction, Iran Newspaper, 2004.
[14] Zaryabi, Hassan, Concept of Kartasys and Refinding It in The Classical, realism and Present century, 1996.

[15] URL 1: (http://www.tebyan.net) (2012-11-05). 